\title{
O sabotażu i dywersji w świetle polskiego ustawodawstwa po 1944 roku
}

Pojęcie dywersji i sabotażu było w powojennej Polsce zjawiskiem, które bardzo często towarzyszyło oporowi społecznemu. Zdaniem władz komunistycznych, które formalnie od 1944 r. przejęły w niej władzę, akcje dywersyjno-sabotażowe postrzegano jako

„gwałtowny akt, w wyniku którego nastąpiło zniszczenie obiektu przemysłowego, jego części, agregatu lub maszyny, mostu lub innego obiektu komunikacyjnego, albo też innego obiektu gospodarczego, jeśli akt ten został dokonany z pobudek kontrrewolucyjnych"'.

Działalność tego rodzaju ówczesne władze dzieliły na dwie zasadnicze grupy $^{2}$. Pierwszą z nich stanowiły wszelkiego rodzaju akcje dywersyjne, takie jak niszczenie mostów kolejowych, powodowanie katastrof na kolei, w kopalniach, zakładach, niszczenie słupów telegraficznych, pożary, uszkadzanie maszyn itp., których trudno było nie dostrzec. Do drugiej grupy wywołującej znacznie większe szkody, należały akcje typowo sabotażowe, polegające na zakłócaniu pracy zakładów produkcyjnych oraz innych obiektów gospodarki państwowej i użyteczności publicznej. Miały one charakter długofalowy, zazwyczaj trudny do wykrycia i stwierdzenia ${ }^{3}$.

Powiązanie pojęcia dywersji i sabotażu nastręczało wiele kłopotów zarówno aparatowi bezpieczeństwa państwa jak i twórcom prawa. Według Igora Andrejewa różnice między tymi terminami były trudne do sprecyzowania. Zgodnie z nim można stwierdzić, że

${ }^{1}$ Archiwum Instytutu Pamięci Narodowej (dalej AIPN), Ministerstwo Spraw Wewnętrznych (dalej MSW), Departament III, sygn. 0297/37, k. 2-3.

2 AIPN, Ministerstwo Bezpieczeństwa Publicznego (dalej MBP), Departament IV, sygn. 01521/77, k. 10-12.

${ }^{3}$ Sabotaż w przemyśle i jego zwalczanie, z. 8, Warszawa 1948, s. 1. 
„sabotaż to świadome uchylanie się od należytego wykonywania obowiązków pracowniczych aby w ten sposób uniemożliwić prawidłową działalność przedsiębiorstwa. Dywersją zaś jest niszczenie lub uszkadzanie środków komunikacyjnych lub łączności, wodociągów, składów lub innych doniosłych obiektów"4.

Określenie „sabotaż” nie jest niczym nowym. W języku potocznym oznacza on dezorganizowanie pracy przez umyślne uchylanie się od niej lub świadome, wadliwe jej wykonywanie, najczęściej przez uszkadzanie, niszczenie środków produkcji lub ukryte zamaskowane działanie mające na celu zakłócanie realizacji jakiegoś planu. Termin „sabotaż” ma swój początek we Francji XIX w. Nazwa jego pochodzi od noszonych przez robotników francuskich drewnianych pantofli ,sabot”, które wtykano w tryby maszyn, co z kolei powodowało ich uszkodzenie lub unieruchomienie nawet na dłuższy okres czasu ${ }^{5}$. Sabotaż w tym okresie ze względu na niską świadomość klasy robotniczej był środkiem walki o poprawę warunków jej bytu ${ }^{6}$. Nadmierna eksploatacja robotników w przedsiębiorstwach kapitalistycznych w XIX w. sprawiła, że zdesperowani pracownicy wtykali swoje saboty w tryby maszyn doprowadzając do ich uszkodzenia lub zakłócenia pracy. Sabotaż był więc swego rodzaju formą protestu robotników przeciwko wyzyskowi, stanowiąc określony przejaw walki klasowej, gdyż nieuświadomieni robotnicy jako główną przyczynę swoich nieszczęść upatrywali maszyny. W miarę upływu czasu wraz z pojawianiem się nowych form sabotażu pojęcie to uległo rozszerzeniu. Obok jawnego, prymitywnego i fizycznego niszczenia jednostkowych urządzeń wystąpiły formy polegająca na utrudnianiu lub nawet uniemożliwianiu prawidłowego funkcjonowania gospodarki kapitalistycznej. We Francji sabotaż przejawiał się w pracy szybkiej lecz mało dokładnej, co ostatecznie doprowadziło do spadku wydajności produkcji. W Anglii polegał na wykonywaniu pracy z drobiazgowym przestrzeganiem wszelkich obowią-

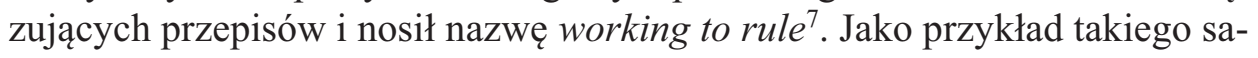
botażu przytaczane są brytyjskie przepisy kolejowe wymagające dokładnego sprawdzenia biletu przejazdowego ,z obu stron”. Sabotujący bileter przy wypuszczaniu podróżnych na peron z całą dokładnością oglądał każdy podany mu bilet w wyniku czego pociąg odjeżdżał, a większa część pasażerów pozostawała na miejscu. Innym przykładem takiego sabotażu, również z dziedziny ruchu kolejowego, było skrupulatne wykonywanie przepisu, nakazującego zwalnianie pociągu przed każdym mostem, przejazdem lub zakrętem.

${ }^{4}$ I. Andrejew, Polskie prawo karne w zarysie, Warszawa 1983, s. 339.

${ }^{5}$ Wielka Encyklopedia Powszechna PWN, t. 10, Warszawa 1967, s. 282.

${ }^{6}$ K. Jabłonowski, Działania operacyjne Służby Bezpieczeństwa w zwalczaniu aktów sabotażu w jednostkach gospodarki uspołecznionej ochranianych przez pion Departamentu V MSW, praca dyplomowa WSO MSW, Legionowo 1987, s. 10.

${ }^{7}$ L. Hochberg, Sabotaż, „Wojskowy Przegląd Prawniczy”, nr 1-2, 1948, s. 39. 
Kierownicy pociągów pośpiesznych ze złośliwą dokładnością wykonujący przepisy doprowadzali do stałych opóźnień. Sabotaż w kolejnictwie nasilił się również we Francji na początku XX w. Polegał on m.in. na kierowaniu do jednej stacji kolejowej większej ilości pociągów. Powodowało to znaczną dezorganizację transportu, gdyż dana stacja nie mogła przyjąć, rozładować i załadować nadmiernej liczby wagonów, zaś w innym miejscu odczuwano ich brak. Powstała sytuacja tak zagroziła gospodarce Francji, że burżuazja do jej likwidacji planowała użyć nielegalnych środków ${ }^{8}$. Efektem tego była zmiana w przepisach francuskiego kodeksu karnego pozwalająca na pociągnięcie do odpowiedzialności karnej sprawców sabotażu dokonywanego również $\mathrm{w}$ takiej formie. W taki sposób przepisami prawnymi burżuazja usiłowała osłabić walkę klasową prowadzoną za pomocą akcji sabotażowych. We Włoszech natomiast popularne było wykonywanie pracy w tempie zwolnionym lub $\mathrm{w}$ formie masowego zorganizowanego przeszkadzania $\mathrm{w}$ wykonywaniu pracy. Jako przykład może tu posłużyć strajk tramwajowy w Genui w 1913 r. podczas którego strajkujący kładli się na szynach tramwajowych, uniemożliwiając jakikolwiek ruch ${ }^{9}$.

Kolejne rozszerzenie zakresu pojęcia sabotażu nastąpiło wraz z wybuchem I wojny światowej. Został on niejako zaakceptowany przez strony wojujące jako środek walki z nieprzyjacielem. Objął on m.in. umyślne uszkadzanie środków komunikacji, maszyn, urządzeń i narzędzi mających związek z produkcją o charakterze wojennym i obronnym, zapasów żywności itp. Dokonywany przez agentów wrogich sobie państw miał na celu osłabienie potencjału zarówno gospodarczego jak i militarnego kraju, w którym akty sabotażu były dokonywane. Szybko zauważono, że jeden sabotażysta w fabryce może skuteczniej zniszczyć ważne urządzenia, niż dywizjon bombowców, a dodatkowo nie pociąga za sobą strat własnych. Znane były fakty sabotażu niemieckiego w Stanach Zjednoczonych Ameryki Północnej, gdzie agenci niemieccy uszkadzali maszyny wielkich okrętów oceanicznych mających udać się do portów państw sprzymierzonych z ładunkiem wojennym lub powodowali na takich okrętach pożary. Szczególny rodzaj „,sabotażu wojennego”, zakrojonego na szeroką skalę, stanowiły akty dywersji. Pojęciem tym określono wrogie działania na terytorium nieprzyjaciela polegające na niszczeniu, unieruchamianiu przez specjalne grupy dywersyjne urządzeń obronnych, węzłów łączności i komunikacji, urządzeń użyteczności publicznej (elektrowni, gazowni, wodociągów itp.). Jako przykład takiego działania może posłużyć operacja „Gunnerside” przeprowadzona w czasie II wojny światowej przez komandosów norweskich. W czasie jej realizacji zniszczono zakłady Norsk Hydro w Vemork - prowincji w Norwegii. Zakłady te produkowały „ciężką wodę”.

\footnotetext{
${ }^{8}$ B. Utiewski, Historia prawa karnego państw burżuazyjnych, Warszawa 1972, s. 202.

${ }^{9}$ L. Hochberg, op. cit., s. 44.
} 
Zniszczeniu uległ zakład oraz 3 tys. funtów „ciężkiej wody”, koniecznej do produkcji broni jądrowej ${ }^{10}$.

Również w Polsce w okresie II wojny światowej sabotaż należał do jednej z najbardziej rozpowszechnionych form walki ruchu oporu z okupantem. Dokonywany był zarówno przez zorganizowane grupy partyzanckie jak i osoby działające indywidualnie. Przybierał najróżniejsze postacie od biernego oporu przejawiającego się w różnego rodzaju bojkotowaniu władzy okupanta poprzez niszczenie oddawanych kontyngentów żywnościowych, uszkadzanie taboru kolejowego itd. Działania sabotażowe na terenie Polski powodowały w potencjale zbrojeniowym Niemiec duże straty, np. w ostatnim kwartale 1941 r. w ich wyniku produkcja przemysłowa okupanta spadła o około $30 \%{ }^{11}$. $\mathrm{Z}$ biegiem czasu pojęcia dywersji i sabotażu objęły wrogie państwu, jego ustrojowi aktywne działania polegające m.in. na niszczeniu, uszkadzaniu, czynieniu niezdatnym do użytku zakładów, urządzeń, obiektów budowlanych, a także innego mienia w celu osłabienia tegoż państwa pod względem politycznym i ekonomicznym, albo na podjętej w tym samym celu dezorganizacji zakładów, urządzeń, instytucji prowadzącej do uniemożliwienia lub utrudnienia prawidłowego ich funkcjonowania. Typizacja opisanych czynów w odrębne stany faktyczne nastąpiła w kodeksach karnych jednak znacznie później, przy czym nie wszystkie kodeksy dokonały takiej typizacji. Znaczna ich większość nie uczyniła tego, uznając to za zabieg zbędny, wobec istnienia wystarczająco licznej grupy typów przestępstw, mogących skutecznie ochronić dobra atakowane dywersją i sabotażem.

Ponieważ PRL przywiązywała dużą wagę do ochrony funkcjonowania gospodarki narodowej, tego typu działalność oczywiście była przez komunistyczny wymiar sprawiedliwości ścigana. Deklarowanym celem było głównie to, aby w drodze surowej represji karnej zapewnić skuteczną eliminację ze społeczeństwa wrogów socjalizmu zagrażających swoim działaniem interesom polityczno-gospodarczym socjalistycznego państwa ${ }^{12}$. Walka z akcjami dywersyjno-sabotażowymi przez władze w Polsce miała podobny charakter jak w ZSRR, gdzie styl ich zwalczania przeniesiono do polskich służb specjalnych. W ZSRR już w okresie rewolucji październikowej 1917 r. miał miejsce pierwszy polityczny charakter sabotażu jako działalności przeciwko ustrojowi państwowemu. Rewolucyjna zmiana stosunków własnościowych, stanowiąca podwalinę nowego ustroju społeczno-ekonomicznego sprawiła, że sabotaż wyrażający się w różnych formach działania stał się jednym ze środków walki klasowej. Taktyka przyjęta przez burżuazję i opozycję zakładała równolegle obok prób zbrojnego obalenia władzy robotniczo-chłopskiej

${ }^{10}$ Mała Encyklopedia Wojskowa, t. I, Warszawa 1967, s. 350.

${ }^{11}$ Ruch oporu w Europie w czasie II wojny światowej, t. III, s. 86.

12 P. Bisek, S. Styk, Ochrona gospodarki narodowej przed przestępstwami, Warszawa 1976, s. $19-21$. 
sabotowanie wszelkich ich poczynań. Dlatego też na wniosek Lenina ${ }^{13}$ Rada Komisarzy Ludowych w grudniu 1917 r. powołała Wszechrosyjską Komisję do Walki z Kontrrewolucją i Sabotażem ${ }^{14}$.

Walka z przejawami skrajnych form oporu społecznego w państwie komunistycznym, a zwłaszcza $\mathrm{z}$ akcjami dywersyjno-sabotażowymi, wymagała nie tylko rozbudowanego aparatu ścigania ale i ustawodawstwa. Przepisami częściowo spełniającymi te warunki w początkowym okresie były wydane przez Radę Komisarzy Ludowych dekrety $O$ sadzie nr 1 i 2, które za jedno z naczelnych zadań stawiały walkę z sabotażem. W drugiej połowie w Rosji powstały pierwsze Trybunały Rewolucyjne. $Z$ tego okresu pochodzi również pierwsza definicja kontrrewolucyjnego sabotażu. Wtedy właśnie po raz pierwszy prawo rozszerzyło pierwotne pojęcie sabotażu jako ,wstrzymywanie się od pracy, czynne naruszanie lub utrudnianie prawidłowego biegu czynności instytucji, hamowanie lub zmniejszanie produkcji przedmiotów pierwszej potrzeby". Po raz pierwszy określono podmiot przestępstwa sabotażu, który stanowił funkcjonariusz służby państwowej lub społecznej. Przedmiotem była zaś instytucja lub przedsiębiorstwo, w którym pełni lub pełnił służbę, a zatem zakład państwowy lub społeczny. Podmiotem tego przestępstwa stać się mógł zatem każdy obywatel (już nie tylko funkcjonariusz służby publicznej), a więc właściciel prywatnego przedsiębiorstwa, wtedy gdy obiektem tego przedsiębiorstwa był zakład wytwarzający produkty masowego spożycia. $Z$ uwagi na niebezpieczeństwo jakie sabotaż stanowił dla ZSRR, Trybunały Rewolucyjne stosowały bardzo surowe wymiary kary, do kary śmierci włącznie. Stosowanie kary śmierci zaniechano po rozgromieniu kontrrewolucji w $1920 \mathrm{r}^{15} \mathrm{~W}$ okresie powstania ZSRR sabotaż został wyłączony z grupy przestępstw o charakterze kontrrewolucyjnym, a jego pojęcie ograniczono do działania polegającego na zaniechaniu i bezczynności ${ }^{16}$. Zawarto to w kodeksie karnym Rosyjskiej Socjalistycznej Federacyjnej Republiki Radzieckiej z dnia 24 V 1922 r. Za tego typu działalność przewidziano od 1 do 10 lat pozbawienia wolności. Zapis brzmiał:

„Przeciwdziałanie normalnej działalności radzieckich instytucji lub przedsiębiorstw albo też normalne ich wykorzystanie w celu zniszczenia lub poderwania państwowego przemysłu, handlu i transportu dla uskutecznienia działań przewidzianych w art. 57 (kontrrewolucja gospodarcza) podlega karze (...)"17.

Również po powstaniu ZSRR dokonano niebawem kodyfikacji prawa karnego w 1926/27 r. Zwiększono też karę na 25 lat pozbawienia wolności

${ }^{13}$ W. I. Lenin, Dzieła, t. 22 , s. 81.

${ }^{14}$ J. Ochmański, Feliks Dzierżyński, „Służba MO”, nr 4-5, 1976, s. 463.

${ }^{15}$ F. Dzierżyński, Pisma wybrane, Warszawa 1951, s. 237-240.

${ }^{16}$ J. Muszyński, Wkład Lenina w tworzenie radzieckiego systemu prawnego, „Wojskowy Przegląd Prawniczy", nr 2195/1970, s. 135-140.

${ }^{17}$ I. Andrejew, Zagadnienia prawa karnego państw socjalistycznych, Warszawa 1971, s. 20. 
w przypadku wystąpienia szczególnie obciążających okoliczności. Stało się to na skutek połączenia sabotażu ze szkodnictwem gospodarczym ${ }^{18}$.

W Polsce międzywojennej ani kodeks karny z 1932 r. ani inne akty prawne $\mathrm{w}$ swoich przepisach nie wymieniały wyraźnie przestępstwa dywersji i sabotażu ${ }^{19}$. Ustawodawca jednak chcąc zabezpieczyć interesy klasy panującej przed aktami sabotażu zawarł $\mathrm{w}$ innych przepisach kodeksowych stany do niego zbliżone. Jednym z nich był art. 105 k.k. obejmujący „,dostawę dla wojska broni lub innego sprzętu niezdatnego do użytku lub też niewykonanie dla wojska w czasie wojny lub grożącej wojny umówionej dostawy, albo wykonanie jej niezgodnie z umową"20. Przepis ten chronił co prawda tylko „wąski wycinek” ówczesnych stosunków społecznych, jednak były to stosunki bardzo ważne, gdyż dotyczące spraw wojskowych. Odpowiedzialność karną za dostawę niewłaściwej jakości broni lub innego sprzętu wojennego ponosił każdy, kto takowe dostarczył, tj. dostawca, pośrednik, pełnomocnik lub funkcjonariusz dostawcy lub pośrednika, a więc wszystkie osoby będące kontrahentami w dostawie oraz pomocnikami kontrahentów. Również w art. 100 k.k. z 1932 r. można się doszukać elementów sabotażu, gdyż działanie na korzyść wroga lub na szkodę siły zbrojnej bądź z nią sprzymierzonej mogło przebiegać $\mathrm{w}$ formie sabotażu ${ }^{21}$. Podobnie wyglądała sytuacja, jeżeli chodzi o rozdział XXXIV zatytułowany Przestepstwa przeciwko urzadzeniom użyteczności publicznej. Przepisy tam zawarte chroniły mienie stanowiące urządzenia użyteczności publicznej przed zamachami sabotażowymi. Także art. 263 k.k. stwarzał warunki pociągnięcia do odpowiedzialności sprawcy dopuszczającego się winy umyślnej sabotażu poprzez uszkodzenie lub czynienie niezdatnym do użytku cudzego mienia. Pod ten artykuł podlegało także uszkodzenie przedmiotów użyteczności publicznej wymienionych w art. 223 i 224 k.k., o ile przez to nie uniemożliwiono ani nie utrudniano powszechnego korzystania z nich (art. 223), względnie prawidłowego ich funkcjonowania (art. 224). W przypadku, gdy sabotażu dopuścił się urzędnik poprzez zaniechanie wykonywania spoczywających na nim obowiązków, mógł odpowiadać wówczas z art. 286 par. 1 k.k. Niedopełnienie obowiązku w myśl tego przepisu powodowało szkodę $\mathrm{w}$ interesie publicznym lub prywatnym ${ }^{22}$.

W okresie postępującego zaostrzenia stosunków międzynarodowych, w 1938 r. został wydany Dekret o ochronie niektórych interesów Państwa ${ }^{23}$. Jego art. 1 zaostrzył odpowiedzialność karną sprawców uszkodzenia lub czy-

${ }^{18}$ P. Lewandowski, Przestępstwo sabotażu w świetle teorii i praktyki, praca dyplomowa WSO MSW, Legionowo 1988, s. 15-18.

${ }^{19}$ Dziennik Ustaw Rzeczpospolitej Polskiej (dalej DzURP), 1932, nr 60, poz. 571.

${ }^{20}$ L. Pejper, Komentarz do kodeksu karnego z 1932 r., s. 243-250.

${ }^{21}$ Ibidem, s. 236, 536.

${ }^{22}$ A. Barciński, Rozwój odpowiedzialności karnej za przestępstwo sabotażu, „Wojskowy Przegląd Prawniczy", nr 4/1977, s. 452.

${ }^{23}$ DzURP 1938, nr 91, poz. 623. 
nienia niezdatnym do użytku przedmiotów bądź urządzeń o charakterze wojskowym służących ochronie Państwa. Z mocy art. 2 pociągnąć można było do odpowiedzialności karnej osoby, które utrudniały lub uniemożliwiały prawidłowe działanie zakładów wytwarzających sprzęt wojskowy. Obydwa przepisy dawały możliwość pociągnięcia do odpowiedzialności karnej autorów sabotażu, jeśli czyn ich skierowany był przeciwko urządzeniom wojskowym, ochrony Państwa lub Sił Zbrojnych. Z treści dekretu oraz jego tytułu wynika, iż chodziło tu o ochronę podstawowych interesów Państwa. Za tezą tą przemawia również sankcja przewidująca dla sprawcy czynu karę więzienia, a więc do lat 15, czyli znacznie wyższą niż dla sprawcy czynu z art. 263 k.k. z 1932 r., której górna granica wynosiła 5 lat pozbawienia wolności ${ }^{24}$. Sankcja ta była nawet bardzo ostra w przypadku zaistnienia wielkiej szkody dla wojskowej obrony Państwa, albo jeśli czyn został popełniony w czasie wojny. Wystąpienie chociażby jednej z w/w okoliczności obciążających powodowało wymierzenie jednej z dwóch kar, a mianowicie kary dożywotniego więzienia lub kary śmierci. Ustawodawca sprecyzował pojęcie „,czasu wojny”, który rozpoczynał się z chwilą ogłoszenia mobilizacji, a kończył się z chwilą zawarcia pokoju.

W Polsce powojennej, równolegle $\mathrm{z}$ budowaniem zrębów władzy sowieckiej, na wzór z ZSRR zaostrzono w ustawodawstwie sprawy związane z działalnością dywersyjno-sabotażową. Uznając, że rozdział XXXVI k.k. z 1932 r. zawierający przestępstwa przeciwko urządzeniom użyteczności publicznej oraz przepis art. 263 mówiący o niszczeniu mienia, nie stanowią dostatecznej ochrony zakładów, instytucji i urządzeń przed ich niszczeniem, uszkadzaniem oraz nie dają gwarancji prawidłowego ich funkcjonowania, PKWN jako ustawodawca w Dekrecie o ochronie Państwa z dnia 30 X 1944 r. ${ }^{25}$ umieścił W art. 5 odpowiedni przepis karny traktujący już wyraźnie o ,aktach sabotażu" w myśl prawodawstwa radzieckiego. Objął on wszelkiego rodzaju sabotaż w czasie wojny, jak uszkodzenie lub niszczenie przedmiotów służących do użytku powszechnego lub obrony Państwa, uniemożliwianie lub utrudnianie działania urzędów, zakładów i instytucji, wytwarzanie niezdatnych przedmiotów powszechnego i wojskowego użytku².

Sprawcą takiego czynu mogła być każda osoba. Strona podmiotowa wyrażała się winą umyślną $\mathrm{w}$ obu zamiarach, gdyż z brzmienia przepisu nie wynikało, że można się było go dopuścić tylko z zamiarem bezpośrednim. Szczególne rodzaje sabotażu polegające na utrudnianiu lub udaremnianiu wprowadzenia w życie reformy rolnej oraz uchylaniu się od świadczeń rzeczowych i osobistych podczas wojny opatrzone zostały sankcjami karnymi zawartymi w art. 2 i 10 tegoż dekretu. Czyny te można było popełnić zarówno przez działanie jak i zaniechanie. Tego typu działalność podlegała w ówczesnych latach sądom wojskowym.

\footnotetext{
${ }^{24}$ L. Pejper, Komentarz do kodeksu karnego..., s. 562.

${ }^{25}$ DzURP 1944, nr 10, poz. 50.

${ }^{26}$ W. Bogucki, Maty kodeks karny znowelizowany, 1946, s. 3-6.
} 
Po zakończeniu wojny na terytorium Polski rozgorzała ostra walka zbrojna z podziemiem niepodległościowym oraz oddziałami UPA. W tych warunkach w 1945 r. wydany został nowy dekret zatytułowany $O$ przestepstwach szczególnie niebezpiecznych $w$ okresie odbudowy Państwa ${ }^{27}$. W pierwszym rozdziale zatytułowanym Przestępstwa przeciw bezpieczeństwu publicznemu zawarty został przepis art. 2 przewidujący odpowiedzialność karną za działalność sabotażową. Traktowano go nadal jako jedno z najcięższych i najbardziej niebezpiecznych przestępstw skierowanych przeciwko Państwu. W porównaniu z poprzednim dekretem ustawodawca opatrzył pewne akty sabotażu surowszą sankcją karną, podwyższając dolną granicę kar z 1 roku do 3 lat więzienia. Odstąpiono jednocześnie od dotychczasowej nomenklatury „przedmiotów i urządzeń służących do użytku powszechnego lub ochrony Państwa" i rozgraniczono wyraźnie czyny sabotażu, którego obiektem były całe zakłady lub urządzenia (art. 2 ust. 1 i 2 nowego dekretu), od czynów sabotażu skierowanych przeciw wydajności pracy (art. 25 ust. 1 dekretu).

Za popełnienie sabotażu w odniesieniu do urządzenia technicznego zakładu oraz do surowca sprawca odpowiedzialny był odtąd w tym tylko przypadku, jeśli należyte starania o te obiekty stanowiły ciążący na nim służbowy obowiązek (art. 25 ust. 2 dekretu). Ponadto wyjęto spod pojęcia sabotażu wytwarzanie niezdatnych przedmiotów powszechnego użytku, karalne pozostało jedynie wytwarzanie takich przedmiotów dla wojska ${ }^{28}$.

W tym samym niemal brzmieniu recypowane zostały przepisy o sabotażu w dekrecie z 13 VI 1946 r. O przestępstwach szczególnie niebezpiecznych $w$ okresie odbudowy Państwa, zwanym popularnie małym kodeksem karnym $^{29}$. Sprawy sabotażu zawarto w przepisie art. $3 \mathrm{w}$ rozdziale obejmującym przestępstwa przeciwko bezpieczeństwu publicznemu. Szczególne przypadki sabotażu zagrożone zostały karami w art. 20 wspomnianego dekretu (sabotowanie reformy rolnej - dyspozycja analogiczna z art. 2 dekretu z dnia 16 XI 1945 r.), w art. 21 (sabotaż wykonania świadczeń rzeczowych), wreszcie w art. 39 dekretu stanowiącym o obniżeniu ze szkodą dla interesów społecznych poziomu wytwórczości, jakości wyrobów lub o zmniejszaniu wydajności pracy w zakładach państwowych, samorządowych lub zarządzanych przez Państwo albo samorząd. W myśl brzmienia art. 3 m.k.k. odpowiedzialności karnej podlegał ten kto dopuszczał się sabotażu przez:

1) niszczenie lub czynienie niezdatnym do użytku zakładów lub urządzeń użyteczności publicznej albo komunikacji publicznej bądź urządzeń służących obronie Państwa Polskiego lub sprzymierzonego;

\footnotetext{
${ }^{27}$ DzURP 1945, nr 53, poz. 300.

${ }^{28}$ L. Hochberg, Sabotaż, „Wojskowy Przegląd Prawniczy”, nr 1-2, 1948, s. 39-44.

${ }^{29}$ DzURP 1946, nr 30, poz. 192.
} 
2) uniemożliwienie lub utrudnianie prawidłowego działania zakładów lub urządzeń wymienionych w pkt. 1;

3) wytwarzanie wbrew warunkom umówionej dostawy dla wojska przedmiotów zupełnie lub w znacznym stopniu niezdatnych do użytku ${ }^{30}$.

Sankcja karna wyżej opisanych czynów przewidywała karę pozbawienia wolności na czas nie krótszy niż 3 lata, dożywocie lub karę śmierci. Znacznie trudniej było sprecyzować kwestie przedmiotowe takie jak ,zakłady użyteczności i komunikacji publicznej”, „urządzenia użyteczności” itp. Z biegiem czasu w oparciu o konkretne przypadki Najwyższy Sąd Wojskowy w swoim orzecznictwie zaliczył do zakładów chronionych przed działalnością dywersyjno-sabotażową m.in. kopalnie, huty, fabryki, zakłady pracy itd. Ochroną prawa również ze względu na zakres i wagę działalności objęto zakłady wytwórcze jak też zakłady świadczące usługi powszechnie dostępne dla ludności lub przeznaczone dla ogółu ${ }^{31}$.

Orzecznictwo sądowe znacznie mniej uwagi poświęcało wyjaśnianiu pojęcia „urządzenia użyteczności publicznej” i „komunikacji publicznej”. Raz utożsamiane były przez Najwyższy Sąd Wojskowy z pojęciem „zakładu”, innym razem określano nimi „ogół sprzętów”, przez co rozumiano maszyny, sprzęt, aparaturę, instalacje i wszelkie przedmioty służące dla prawidłowego działania zakładów, o których była mowa w art. 3. Zbyt wąsko artykuł ten również ujmował stronę przedmiotową czynu. Użyty zwrot „,opuszcza się aktów sabotażu" stanowił tylko ogólne znamię charakteryzujące się w czynach opisanych w punktach 1-3. Czynami tymi było niszczenie lub czynienie niezdatnym do użytku, uniemożliwienie lub utrudnianie prawidłowego działania, wytwarzanie wbrew warunkom umówionej dostawy określonych przedmiotów. Przepis ten objął zarówno dywersję (pkt 1), jak i sabotaż w ścisłym tego słowa znaczeniu (pkt 2). O ile pojęcie dywersji zostało dość jasno określone, to działanie opisane w pkt. 2 wymagało dokładniejszego sprecyzowania. Przyniosło je orzecznictwo Sądu Najwyższego, który rozpatrując różne formy sabotażu, zaliczył do działań o takim charakterze m.in. w komunikacji bezpodstawne zahamowanie pociągu, w handlu niezgłoszenie towarów reglamentowanych lub ich wolną sprzedaż i uniemożliwienie wykonywania planów, w rolnictwie dopuszczanie do ginięcia ziemiopłodów, zmniejszenie plonów przez opóźnienie zasiewów, w budownictwie usuwanie czynnika konkurencyjnego przy przetargach, zamrażanie wielomilionowych sum skarbowych oraz wyzbywanie się materiałów reglamentowanych itp. W miarę upływu czasu Najwyższy Sąd Wojskowy zaprzestał kazuistycznego wyliczania i uchwałą Zgromadzenia Ogólnego z 12 V 1954 r. zobowiązał sądy przy interpretacji art. 3 dekretu z 13

\footnotetext{
${ }^{30}$ DzURP 1946, nr 30, poz. 192.

${ }^{31}$ Uchwała sktadu Siedmiu Sędziów z dnia 14 VI 1962 r., [w:] Orzecznictwo Izby Karnej i Izby Wojskowej Sądu Najwyższego, nr 3, 1963, s. 10-13.
} 
VI 1946 r. do wyodrębnienia w stronie przedmiotowej przestępstwa sabotażu, czyli:

1) aktów dywersji (art. 3, pkt. 1) - polegających na działaniu skierowanym na naruszenie substancji przedmiotów, np. przez umyślne uszkodzenie, złamanie, zepsucie, rozbicie, wybuch, podpalenie, albo na fizycznym oddziaływaniu np. poprzez rozmontowanie, usunięcie itp.;

2) aktów szkodnictwa (art. 3, pkt. 2 i 3) - polegających na umyślnym pogarszaniu jakości wyrobów, zwalnianiu tempa wytwórczości, budownictwa, obrotu, na umyślnie wadliwym planowaniu, nieracjonalnym wykorzystywaniu maszyn, sprzętu, środków transportu i innych;

3) aktów sabotażu (art. 3, pkt 2) - stanowiących umyślne wstrzymywanie się sprawcy od wykonania obowiązków, które polegają na celowo opieszałym ich wykonywaniu w nienależyty sposób ${ }^{32}$.

Uchwała powyższa nałożyła ponadto na sądy obowiązek ustalania postaci tego przestępstwa i wymieniania nazwy postaci w orzeczeniu. W tym stanie rzeczy przyjęto, iż stronę przedmiotową przestępstwa $\mathrm{z}$ art. 3 wypełnia każdy czyn, tj. działanie lub zaniechanie, który wywołuje skutki opisane w poszczególnych punktach przepisu. Jako podmiot przestępstwa określono osobę działającą w zamiarze wrogim Polsce Ludowej, z tym że podmiotem aktu dywersji mógł być każdy, zaś podmiotem aktu szkodnictwa lub sabotażu tylko osoba pełniąca jakiekolwiek obowiązki w zakładzie lub z zakładem współdziałającym lub osoba, na której spoczywały obowiązki mające istotne znaczenie dla gospodarki narodowej ${ }^{33}$.

Akt sabotażu zachodził nie tylko wtedy, gdy został świadomie i celowo popełniony przez sprawcę, po to aby zniszczyć lub uczynić niezdatnym do użytku przedmiot chroniony przez art. 3 lub też by uniemożliwić prawidłowe jego działanie. Sprawca podlegał również odpowiedzialności za działanie z pobudek osobistych, gdy miał na celu inne zupełnie względy, np. chęć osiągnięcia korzyści materialnych, lecz przy tym przewidywał przestępczość swego działania lub możliwość nastąpienia skutku swego działania i na to z góry się godził. Także w swoim orzecznictwie Najwyższy Sąd Wojskowy do końca lat czterdziestych uznawał, że, poza umyślnością czynu, pobudki ani cel działania sprawcy nie stanowiły elementów charakteryzujących stronę podmiotową sabotażu. Skutkiem tego, praktyka charakteryzowała się tendencją do rozszerzającego stwarzania omawianego przepisu. Znamion sabotażu dopatrywano się wówczas w każdym działaniu polegają-

${ }^{32}$ Uchwała Zgromadzenia Ogólnego 64/54, [w:] Zbiór Orzeczeń Najwyższego Sądu Wojskowego, Warszawa 1954, s. 31-40.

${ }^{33}$ Okólnik Sądownictwa Wojennego z 22 I 1945 r., „Wojskowy Przegląd Prawniczy”, nr 2/1945, s. 106-111. 
cym na niszczeniu lub uszkadzaniu zakładów lub urządzeń użyteczności publicznej. Między innymi za sabotaż skazano sprawców odcinających węże hamulcowe od wagonów PKP po to, aby uzyskać gumę na podzelowanie obuwia. Pod koniec lat czterdziestych o sabotaż oskarżono 12 pracowników Wydziału Inspekcji Budowlanej Prezydium Rady Narodowej miasta st. Warszawy, zarzucając im sabotowanie odbudowy stolicy polegające na tym, że za łapówki zezwalali na tzw. „dzikie budownictwo”, zmieniali plany urbanistyczne na korzyść tych co wręczali łapówki i tolerowali inne akty samowoli budowlanej ${ }^{34}$.

$\mathrm{Na}$ początku lat pięćdziesiątych Najwyższy Sąd Wojskowy stanął na stanowisku, że przestępstwo z art. 3 m.k.k. ma charakter kontrrewolucyjny i może być ono dokonane w zamiarze wynikającym z pobudek antypaństwowych i wrogich PRL. Tego rodzaju ukształtowanie praktyki organów ścigania spowodowało znaczne zawężenie stosowania przepisu art. 3 m.k.k. W kwietniu 1955 r. w wyniku uchwalenia ustawy o przekazaniu sądom powszechnym dotychczasowej właściwości sądów wojskowych w sprawach karnych osób cywilnych, funkcjonariuszy bezpieczeństwa publicznego, MO i Służby Więziennej nastąpiło przekazanie sądownictwu powszechnemu orzekania również w sprawach sabotażu ${ }^{35}$. Praktyka represyjna sądów opierała się w początkowym okresie na wytycznych Najwyższego Sądu Wojskowego. Skutkiem tego w sprawach, które nie zostały zakwalifikowane jako sabotażowe, a polegały na niszczeniu lub uszkadzaniu zakładów lub urządzeń w sytuacji, gdy sprawcy nie zdołano udowodnić pobudek politycznych, kształtowała się łagodnie i nie odpowiadała wymogom prewencji ogólnej oraz społecznej szkodliwości czynów. Wymagało to ponownej zmiany wytycznych Najwyższego Sądu Wojskowego, co nastąpiło w uchwale Sądu Najwyższego w składzie 7 sędziów z dnia 14 VI $1962 \mathrm{r}^{36}$ Uchwała ta w zakresie strony podmiotowej wyjaśniała, że przestępstwo sabotażu może być dokonane tylko w zamiarze bezpośrednim. Odstąpiono natomiast od konieczności udowodnienia politycznych pobudek działania sprawcy, tzn. ustalenia, iż motywem jego działania była wrogość do ustroju PRL.

Z. Cieślikowski napisał, że ,niekorzystne zjawiska występujące w gospodarce narodowej mają swe przyczyny bądź w zdarzeniach niezależnych od woli człowieka, bądź są wynikiem jego określonego zachowania, działania lub zaniechania" ${ }^{37}$. Jednak sfera przeżyć psychicznych sprawcy, w której rodzą się pobudki, jest zwykle w postępowaniu karno-sądowym dowodowo trudno

${ }^{34}$ F. Rafałowski, Ściganie przestępstw o charakterze sabotażu, „Biuletyn Prokuratury Generalnej", nr 7, 1964, s. 7.

${ }^{35}$ Dziennik Ustaw Polskiej Rzeczpospolitej Ludowej (dalej DzUPRL), 1955, nr 15, poz. 83.

${ }^{36}$ AIPN, MSW, sygn. 001708/3187, k. 36.

${ }^{37}$ Z. Cieślikowski, Niektóre problemy ochrony gospodarki narodowej $w$ działaniach resortu Spraw Wewnętrznych, „Problemy Kryminalistyki”, nr 109-110, 1974, s. 50-54. 
uchwytna. Uzależnienie oceny działania bądź zaniechania, które przedmiotowo stanowiły akt sabotażu od ustalenia rzeczywistych politycznych i antypaństwowych pobudek działania sprowadzałoby się w praktyce do zawężenia ścigania ich autorów. Zazwyczaj nie przyznawali się oni do działania z pobudek wrogich PRL i wskazywali częstokroć na inne motywy, które zazwyczaj dotyczyły spraw przyziemnych - chęci zemsty na koledze z pracy, zrobienie żartu itp. ${ }^{38}$

Określeniem zbliżonym do sabotażu był ,mały sabotaż gospodarczy” zwany „szkodnictwem gospodarczym”, obecny w prawodawstwie tuż po wojnie. W dekrecie O przestępstwach szczególnie niebezpiecznych $w$ okresie odbudowy Państwa zawarty został w art. $39^{39}$. W myśl przepisu bezpośredni przedmiot ochrony stanowiła prawidłowa działalność przedsiębiorstw państwowych, samorządowych i społecznych. Ustawodawca określił stronę przedmiotową jako

działanie polegające na obniżaniu poziomu wytwórczości poprzez pogarszanie jakości wyrobów, zmniejszaniu wydajności pracy własnej albo podległego personelu, uchylaniu się od wykonywania obowiązku przedsiębrania należytych starań o urządzenie techniczne zakładu albo o jego surowce lub towary wskutek czego sprawca marnotrawił surowce lub towary, bądź pogarszał stan tych urządzen ${ }^{40}$.

Sabotaż gospodarczy z art. 39 m.k.k. był przestępstwem materialnym. Aby ustalić, że sprawca obniżył poziom wytwórczości, należało stwierdzić, że istotnie pogorszono jakość wyrobów produkowanych przez określony zakład bądź, że istotnie zmniejszyła się wydajność pracy sprawcy lub osób, które mu podlegały. Przedmiot przestępstwa stanowiły wyroby przez pogorszenie jakości, których sprawca obniżał poziom wytwórczości, pracą własną lub podległego personelu, której wydajność zmniejszał, urządzenia techniczne zakładu, surowce oraz towary, w stosunku do których uchylał się od spoczywającego na nim obowiązku przedsiębrania należytych o nie starań. Przedmiotem „małego sabotażu” z art. 39 m.k.k. mogła być tylko osoba pracująca w uspołecznionych zakładach przemysłowych bądź zakładach nieupaństwowionych, ale działających z udziałem finansowym państwa lub pod jego zarządem. Stronę podmiotową przestępstwa charakteryzował zamiar z pobudek politycznych. Mogło ono zostać popełnione z winy umyślnej zarówno w zamiarze bezpośrednim, jak i ewentualnym. W 1969 r. pojęcie „małego sabotażu gospodarczego" zostało jeszcze raz znowelizowane, zatem nawiązujący dotąd do art. 39 m.k.k. czyn odbiegał znacznie od obowiązujących przepisów prawnych. Przestępstwo to, określone w art. 220 k.k., było działaniem nowym o bardzo zawężonym zakresie przedmiotowym i nieco poszerzonym zakresie podmiotów. Tak więc, mały sabotaż gospodarczy popełniał ten, kto

\footnotetext{
${ }^{38}$ Wyrok z dnia 10 XI 1962 r., [w:] Zbór Orzeczeń Sądu Najwyższego, nr 1/1963, poz. 10, s. 11.

${ }^{39}$ DzURP 1946, nr 30, poz. 192.

${ }^{40}$ W. Bogucki, Mały kodeks karny znowelizowany, 1946, s. 11-23.
} 
niszczył, uszkadzał lub czynił niezdatnym do użytku urządzenia techniczne lub utrudniał korzystanie $\mathrm{z}$ nich, powodując przez to istotne zakłócenia w produkcji, transporcie lub łączności. Sprawca podlegał karze pozbawienia wolności na czas nie krótszy niż 3 lata. Jak wynika z zapisu, bezpośrednim przedmiotem ochrony było tu zabezpieczenie tylko produkcji, transportu lub łączności, nie zaś wielu gałęzi gospodarki ${ }^{41}$. Do urządzeń wymienionych w tym przepisie zaliczono wszelkiego rodzaju aparaturę, instalacje, armaturę, mechanizmy, maszyny, dźwigi, transportery, przyrządy itp., które stanowiły bazę techniczną i były wykorzystywane w produkcji, transporcie i łączności. Sąd Najwyższy zaliczył do nich także drogi, mosty i wszelkie środki komunikacji i łączności ${ }^{42}$. Dla tego przestępstwa nie było także istotne czy były one mieniem cudzym czy własnością samego sprawcy, który je zniszczył lub uszkodzi1 ${ }^{43}$.

Uchwalony w 1969 r. kodeks karny przyjął w art. 127 rozwiązanie znacznie odbiegające od uregulowania przestępstwa sabotażu zawartego w poprzednio obowiązującym ustawodawstwie. Przestępstwo to zamieszczone zostało w rozdziale XIX w grupie czynów skierowanych przeciwko podstawowym interesom politycznym i gospodarczym państwa. Zarówno uprawianie dywersji, jak i sabotażu podlegało od tej pory pozbawieniu wolności na okres nie krótszy niż 5 lat albo karze śmierci. Zgodnie z brzmieniem przepisu art. 127 k.k.

sabotażu dopuszcza się ten, kto w celu osłabienia władzy ludowej, wywołania zaburzeń nastrojów powszechnego niezadowolenia albo poważnych zakłóceń w funkcjonowaniu gospodarki narodowej:

1) niszczy, uszkadza lub czyni niezdatnym do użytku zakłady lub urządzenia albo inne mienie o poważnym znaczeniu dla Polskiej Rzeczypospolitej Ludowej;

2) uniemożliwia lub utrudnia prawidłowe funkcjonowanie zakładów, urządzeń albo instytucji o poważnym znaczeniu dla Polskiej Rzeczypospolitej Ludowej ${ }^{44}$.

Według powyższych przepisów działanie sprawcy sabotażu mogło również wyrażać się $\mathrm{w}$ takim postępowaniu, które nie niszcząc ani nie uszkadzając substancji fizycznej przedmiotu, powodowały jednak ten sam skutek. Mogło to nastąpić na przykład przez niedopuszczenie załogi przedsiębiorstwa do stanowisk pracy, spowodowanie niepotrzebnego remontu, rozmontowywanie urządzeń zasilających zakład w energię, siłę, parę, ciepło, opóźnienia w przyjęciu surowców oraz wszelkie inne podobne negatywne oddziaływania

${ }^{41}$ Orzecznictwo Sąu Najwyższego - Izba Karna i Wojskowa, nr 3, 1963, poz. 42.

${ }^{42}$ O. Chybiński, W. Gutekunst, W. Świda, Prawo karne - część szczególna, Warszawa 1971, s. 307 .

${ }^{43}$ E. Szwedek, Szkodnictwo gospodarcze, „Problemy Praworządności”, nr 3, 1971, s. 4.

${ }^{44}$ I. Andrejew, Kodeks karny z komentarzem, Warszawa 1973, s. 399. 
na prawidłowe funkcjonowanie zakładów, urządzeń i instytucji ${ }^{45}$. W ustawodawstwie przewidziano też sytuacje nietypowe, wszak nie zawsze sabotaż był zindywidualizowany. Do takich zaliczono na przykład osoby działające „,na zewnątrz" zakładu i instytucji, a dezorganizujące ich prace. Chodzi tu przede wszystkim o zakłócanie audycji radiowych, telewizyjnych lub połączeń telefonicznych z zewnątrz za pomocą urządzeń nadawczych przez podmiot podłączający się do przewodów łącznikowych albo emitujących sygnały w paśmie fal radiowo-telewizyjnych ${ }^{46}$.

Do przepisów, które równocześnie sprawca mógł naruszyć w przypadku popełnienia sabotażu, władze komunistyczne w niektórych przypadkach zaliczały wówczas: zdradę Ojczyzny opisaną w art. 122 k.k., zamach stanu $\mathrm{z}$ art. 123, dezinformację wyszczególnioną $\mathrm{w}$ art. 131 k.k., afery gospodarcze oraz dewizowo-przemytnicze opisane w art. 134 i 135 k.k., zabójstwo człowieka, a także zawarte $\mathrm{w}$ rozdziale XX artykuły tyczące się przestępstw przeciwko bezpieczeństwu powszechnemu ${ }^{47}$. Do jednych z najbardziej nietypowych przestępstw, które zakwalifikowano pod sabotaż należały tzw. ,akty terroru politycznego" przewidziane w art. 126 k.k. Oznaczało to, że za malowanie antypaństwowych napisów na drzwiach mieszkań lub w miejscu pracy funkcjonariuszy aparatu państwowego, wrzucanie do pomieszczeń, gdzie przebywają, cuchnących substancji, jak też wysyłanie szkalujących anonimów, nękanie telefonami, profanowaniu pomników, symboli komunistycznych, cmentarzy, napadów połączonych z rozbrajaniem, uprowadzenia itp., można było prawnie odpowiadać tak jak za sabotaż. Oczywiście wszystko zależało od ciężaru gatunkowego popełnionego czynu i wiele spraw rozpatrywano indywidualnie, zatem orzeczenie sądu bywało różne. Biorąc pod uwagę wszystkie nadmienione uwagi w sprawie dywersji i sabotażu oraz kar za nie przewidzianych w ustawodawstwie, w konsekwencji napisano, że ,sabotaż może przyczynić się do osłabienia mocy obronnej Państwa"48.

Pojęcia dywersji i sabotażu, na trwałe obecne w prawie polskim, zwłaszcza w okresie PRL należały do przestępstw, na które ustawodawstwo komunistyczne było szczególnie uczulone. Wszak zagrożenie nimi wiązało się z paraliżowaniem i utrudnianiem funkcjonowania gospodarki opartej na własności państwowej. Filozofia ówczesnych władz w wielu przypadkach sprowadzała się do tego, że prawie w każdym stwierdzonym fakcie zniszczenia lub

${ }^{45}$ K. Mioduski, Przestępstwa przeciwko interesom Polskiej Rzeczypospolitej Ludowej, Warszawa 1971, s. 26.

${ }^{46}$ H. Popławski, R. Skarbek, Przestępstwo sabotażu, ,Zeszyty Naukowe Wydziału Prawa i Administracji Uniwersytetu Gdańskiego", z. 7, Gdańsk 1977, s. 64.

${ }^{47}$ A. Barciński, Z rozważań nad zbiegiem przepisów ustawy w przypadku popetnienia przestępstwa sabotażu, „Wojskowy Przegląd Prawniczy”, nr 1/1979, s. 87.

${ }^{48}$ K. Buchała, Kumulatywna kwalifikacja przestepstw komunikacyjnych, „Nowe Prawo”, nr 11, 1972, s. 1615. 
też uszkodzenia mienia państwowego dopatrywano się działań sabotażowych o wymowie antypaństwowej, nawet gdy de facto tak nie było. Przekonanie takie istniało aż do $1990 \mathrm{r}$.

We współcześnie obowiązującym w Polsce kodeksie karnym istnieje jedynie sabotaż komputerowy. Zgodnie z artykułem 269 k.k. polega on na niszczeniu, uszkadzaniu, usuwaniu oraz zmianie danych informatycznych o szczególnym znaczeniu dla obronności kraju, bezpieczeństwa w komunikacji, funkcjonowania administracji rządowej, organu państwowego, instytucji państwowej albo samorządu terytorialnego, jak też zakłócaniu i uniemożliwianiu automatycznego przetwarzania, gromadzenia lub przekazywania takich danych. Sabotaż tego rodzaju zagrożony jest karą pozbawienia wolności od pół roku do lat 8 . Karalności podlega też niszczenie, uszkadzanie lub zmienianie komputerowego urządzenia służącego do automatycznego gromadzenia, przetwarzania i przesyłania informacji ${ }^{49}$. 